with cultivated cotton. Ellstrand cites similar evidence for at least another nine species. $\mathrm{He}$ also documents in great detail the history of sugar beets in Europe, where hybrids between cultivated beets and their progenitors, the sea beets, have caused major weed problems.

Everyone interested in the effects of cropping on plant biodioversity, the evolution of weeds and the risks of GM crops should read this book. Critics and supporters of transgenic crops will continue to debate whether the relatively benign environmental and agronomic disadvantages of GM crops have been due to largely to luck or to an adequate regulatory system. Ellstrand reminds us in detail that the reliability of future successes depends on more careful risk assessment of hybridization with wild relatives.

Rick Roush is director of the University of California Statewide Integrated Pest Management Program, based at University of California, Davis, California 95616, USA.

\title{
Japan's secret weapons
}

\section{A Plague Upon Humanity: The Secret Genocide of Axis Japan's Germ Warfare Operation \\ by Daniel Barenblatt \\ HarperCollins: 2004. 256 pp. US\$25.95, Can\$35.95. To be published in the UK in March 2004 by Souvenir Press, £20}

\section{Alastair Hay}

When Japan invaded Manchuria in 1931, it alleged Chinese involvement in blowing up a section of the Japanese-owned South Manchurian Railway. The charge was false: confessions in 1945 by some of those involved confirmed that Japanese engineers carried out the attack to provide the pretext for the invasion of the Asian mainland. History is littered with similar pretexts.

Condemnation of Japan's invasion by the League of Nations followed relatively swiftly, prompting Japan to leave the body in 1933. Japan subsequently attacked China in 1937 and the US naval base at Pearl Harbor in 1941, and then invaded Vietnam, Malaysia and the Philippines. The brutality of the invaders has been well documented and the success of the military campaign waged by Japan is now textbook material.

Less well known are some of the means that Japan used to get its way, and biological warfare is just one of these. Daniel Barenblatt's A Plague Upon Humanity is an attempt to redress this ignorance and to provide a readable book that documents what happened. Barenblatt is bemused, asking himself how it is that the "startling" information about Japan's use of biological warfare "is not common knowledge, as is the Holocaust and the experiments of the Nazi doctors?"

A Plague Upon Humanity addresses this question, the succinct answer to which is political expediency. Following the defeat of Japan in the Second World War, Japanese scientists and doctors involved in the biological-warfare programme did a deal with the United States. The arrangement was that the United States would receive details of the programme and results of experiments, and in return the Japanese researchers would receive immunity from prosecution. The deal only became public knowledge in 1980 .

As far as the United States was concerned, the information it received was a windfall. Not only had the Japanese used plague, cholera, paratyphoid and anthrax in attacks on Chinese civilians, but they had also carried out experiments on some 3,000 people. These experiments are some of the most gruesome recorded, and many involved deliberately infecting people. Individuals primarily locals who had infringed the Japanese penal codes - were exposed to a single bacterial or viral agent and monitored. As the disease progressed, those infected (the maruta, or 'logs of wood', as they were often called) were assessed on a daily basis; official records show that some were even operated on while still alive. But none survived their ordeal - all 3,000 either succumbed to the infection or were killed and their tissue retained.

The Japanese tested at least 19 bacteria and viruses as candidates for biological warfare. Writing about this in 1947, Edwin Hill, chief of basic sciences at Camp Detrick in the United States, the main research centre for biological warfare, noted that his government had obtained the data for a "mere pittance by comparison with the actual cost of the studies". The value of the data was not in question for, as Hill observed: "Such information could not be obtained in our own laboratories because of scruples attached to human experimentation." Hill does not seem to comment on the scruples of those who use the information or who failed to prosecute the scientists for war crimes.

None of the above is new information, and most of it is retold in Barenblatt's book. Drawing heavily on already published works, particularly Factories of Death by the late Sheldon Harris and Unit 731 by Peter Williams and David Wallace, this latest addition to the literature is something of a disappointment. Barenblatt is right to be outraged about his subject matter and the fact that it still remains relatively obscure; perhaps his book will reach a wide audience and fulfil one of his aims. But for researchers in this field, his book will be a let-down. The sources of the many facts cited in the text are not referenced. Given that the material is so outrageous, it is all the more important to be scrupulous about documenting its origins.
Japan's biological-warfare programme was the brainchild of Shiro Ishii, an immunologist who inveigled his way into Japan's military hierarchy and pushed at an open door to get the funding he needed. His supporters were persuaded that biological warfare would assist Japan's imperial ambitions, enabling Ishii to set up shop in Manchuria at a centre known as Unit 731. Barenblatt demonizes Ishii, and there is much to condemn, but the actions of this rogue scientist are not new. What is missing from Barenblatt's book, and what is sorely needed, is solid evidence of the number of Chinese who died as a result of Japan's use of biological warfare in the field. Sadly, there are few Chinese scholars working in this area with access to the necessary archives.

Barenblatt refers to Chinese sources who claim that as many as 580,000 died as a result of Japan's biological warfare. The figure is said to be preliminary: the number may increase as house-to-house enquiries by investigators turn up more victims. Whether these deaths are truly attributable to the biological-warfare programme, or are the result of insanitary conditions brought about by mass population movements in war, is not clear. What is beyond dispute, however, is that Japan used biological warfare to kill many people. The more people who know this, and about those who did deals to suppress the information, the better. Alastair Hay is professor of environmental toxicology, School of Medicine, University of Leeds, Leeds LS2 9JT, UK.

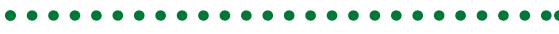 Love, actually}

\section{Why We Love: The Nature and Chemistry of Romantic Love}

by Helen Fisher

Henry Holt: 2004. \$25, 288 pp.

\section{Alison Jolly}

Tristan is on the road with Iseult, who is planning to marry his uncle, Mark. They shoot up a potion of dopamine and noradrenaline enhancer, take one look at each other and fall in love. A serotonin suppressor ensures that the passion becomes obsessive. Delirious with joy, Tristan answers an advertisement from his university at Rutgers, New Jersey, recruiting lovestruck undergraduates to have their brains scanned. In the analysis, his caudate nucleus shines out, a part of the ancient reptilian brain tuned to anticipate and discriminate between rewards. So too does his ventral tegmental area, producing ever more dopamine to drench his emotions. As Helen Fisher writes: "When I first looked at those brain scans, with the active brain regions lit up in bright yellow and deep orange, I felt the way I feel on a summer night when 


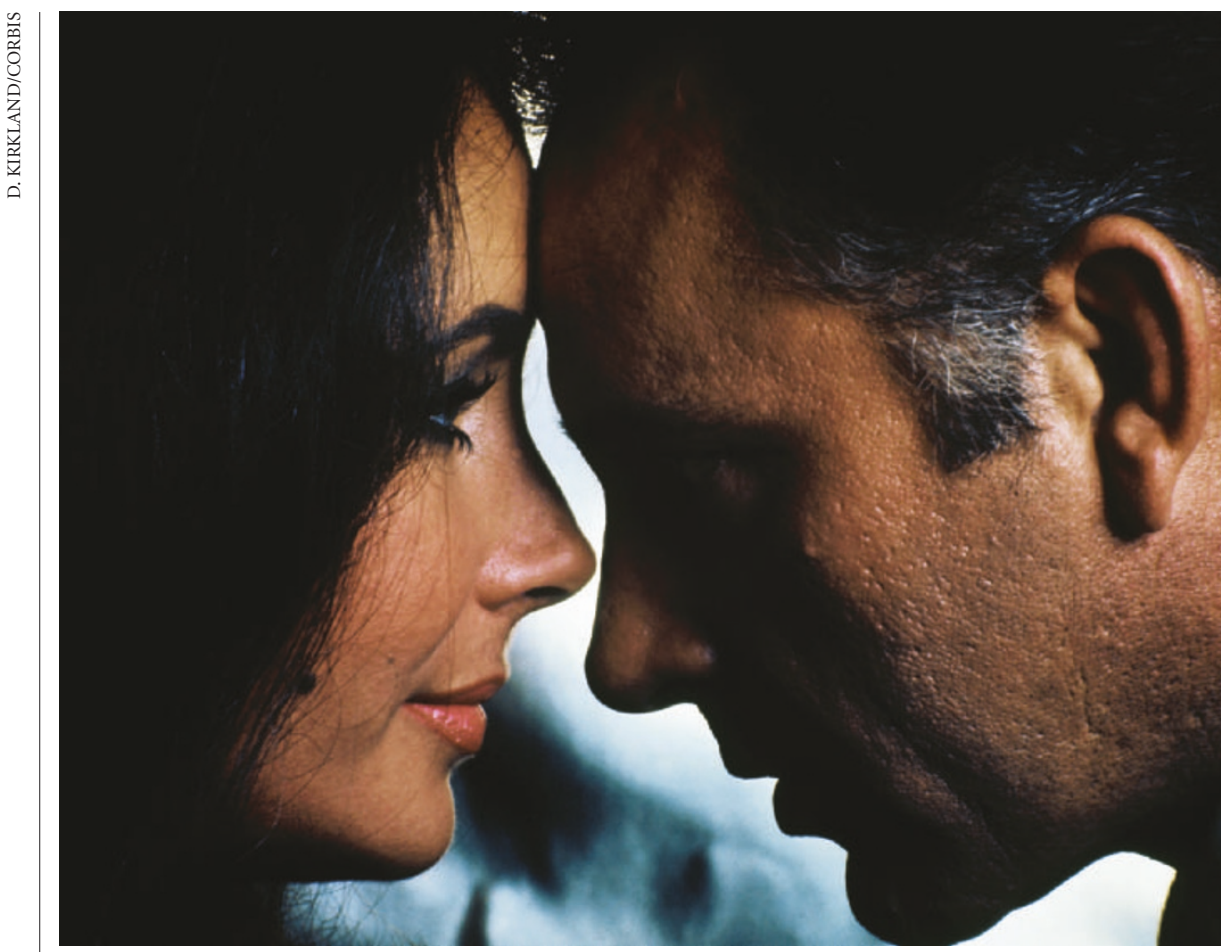

The chemistry's right: it was love at first sight for Richard Burton when he met Elizabeth Taylor.

I gaze at the sparkling universe: overwhelming awe."

Fisher's populist book attempts to explain the mechanism of romance. It is snappily written and filled with quotations. Here's Richard Burton's first sight of a 19-year-old Elizabeth Taylor: "She was so extraordinarily beautiful I nearly laughed out loud. She... was famine, fire, destruction and plague... Her breasts were apocalyptic, they would topple empires before they withered... those huge violet eyes... had an odd glint... Aeons passed, civilizations came and went while these cosmic headlights examined my flawed personality. Every pockmark on my face became a crater of the moon."

Fisher's thesis is that headlong infatuation is a universal human trait. The brain scans she has made of volunteers in and out of love, and their chemical background, are the scientific kernel of the story. The book's aim is to interest people who are fascinated by love found or love lost, with a light hand on the science side.

What interests me is what Fisher does not say. She makes a deliberate choice to ignore the mind-brain and evolution-culture controversies of recent decades. She does not bother justifying her approach. She quotes sociobiologists and evolutionary psychologists as sources, with no mention that they still raise many people's hackles. She simply describes a mating system that sets our emotions on fire at the sight and touch of a beloved individual, but where lust, companionship and romance do not map perfectly onto each other. Then she speculates how this system enables the successful propagation of a species that needs commitment between partners, at least during the first four years of a dependent child's life. So far, I am with her. It is high time we outgrew the phlogiston theory of biology-free humans.

However, she also chooses to ignore the ethics of her studies. This worries me more. She accepts a chemical-based society. When love is lost, depression sets in. In mild form, it is adaptive, enabling the jilted lover to let go. In extreme forms, it is horror. Fisher reports that currently "some 7.1 million Americans take serotonin boosters to counter depression, stress, bereavement, or the despair of tragic love". She doesn't strongly advise that you join them, but points out that anything is better than suicide. When you are ready your medication. Serotonin boosters could block romantic obsession, trivializing your next relationship.

I conclude that King Mark does not stalk Iseult or menace Tristan, her knightly lover. His first love potion having gone astray, he simply doses Iseult with an antidote before readministering the potion, making sure this time that she looks at him, not Tristan. Tristan is still obsessed by old-fashioned romantic love, ignoring its chemical bases. $\mathrm{He}$ sneaks into the castle disguised as a jester. His faithful hound recognizes his smell, but not only does Iseult not recognize him, she does not even care. Now you can decide the story's end. Does Tristan die of a broken heart? Or does King Mark don a doctor's white coat and advance on his rival, syringe in hand not to murder Tristan, but to erase his love? Alison Jolly is in the Department of Biology and Environmental Sciences, Sussex University, Brighton BN1 9QG, UK. to fall in love again, she suggests reviewing

\section{Fossils off the record}

\author{
To See the Fellows Fight: Eye \\ Witness Accounts of Meetings of \\ the Geological Society of London \\ and its Club, 1822-1868 \\ edited by John C. Thackray \\ British Society for the History of Science \\ (Monograph no. 12). 2003. 244 pp. \\ $\mathfrak{L} 15, \$ 26$
}

\section{Martin Rudwick}

The Geological Society of London, founded in 1807 , was one of the first learned societies to be devoted to a specific science, and it was the first in the world to be devoted to geology. The most significant feature of its early meetings was one that nowadays we take for granted: it was agreed to allow discussion of the papers that were read.

This was in stark contrast to what was customary at the Royal Society, and at learned societies generally, where comments were relegated to private conversations after the formal meeting had ended. There was a fear that if discussion were allowed within a meeting it might degenerate into abusive argument, and that this would undermine the public image of the sciences as bodies of factual knowledge, about which there could not properly be divergent opinions.

In the event, however, the Geological Society's decision to allow discussion was vindicated, and other scientific bodies eventually adopted the same custom. It signalled a tacit acceptance of the vital role of argument and disagreement in the process of establishing and improving scientific knowledge. The Geological Society's meetings became famous for their lively arguments. As the editor of the Tory intellectual Quarterly Review commented: "I don't much care for geology, but I do like to see the Fellows fight."

This memorable quote has been used as the title for the late John Thackray's valuable collection of contemporary reports of the meetings of the Geological Society in its early decades. The brief official record of the titles of the papers read is followed by excerpts from letters and private journals reporting or commenting on the discussions or on the papers themselves. No formal account of the discussions was published, so these are the only evidence of what those present thought of the papers. Some other valuable accounts are of discussions at the society's informal dining club, rather than its formal meetings.

The collection starts in 1822, with an occasion that epitomizes the star-studded period in the history of English geology that had by then begun. William Buckland of Oxford University described at the club's dinner table how he had reconstructed the ecosystem of 'ante-diluvial' (Pleistocene) 